\title{
Organizational Politics, Psychological Empowerment And Organizational Commitment: Empirical Evidence From Pakistan
}

Naheed Atta, Government Islamia College for Women, Pakistan

Muneer Ahmad, Lahore School of Economics, Pakistan

Inayat Mangla, Western Michigan University, USA

Dan Farrell, Western Michigan University, USA

\begin{abstract}
Despite its ubiquity in organizations, organizational politics may be viewed negatively by managers. When managers empower employees, the effect of organizational politics may be moderated. This study of Pakistani managers $(n=357)$ demonstrates that organizational politics changes from having a negative effect on employee commitment to a strong positive effect when employees perceive psychological empowerment. The study also validates the use of existing measurement scales in non-Western cultures.
\end{abstract}

Keywords: Organizational Commitment; Organizational Politics; Psychological Empowerment

\section{INTRODUCTION}

ncluding organizational commitment as a major employee attitude construct has advanced management understanding in a wide range of workplace behavior. Organizational commitment has been strongly linked to organizational citizenship (Cropanzano, Rupp, \& Byrne, 2003), firm growth and performance (Antoncic \& Antoncic, 2011), as well as turnover and absenteeism (Mowday, Porter, \& Steers, 1982; Rusbult, Farrell, Rogers, \& Mainous, 1988). While the overriding trend has been to identify positive outcomes of employee commitment, there are empirical studies linking cost and time overruns in over 40 percent of all information technology projects (Desai \& Chulkov, 2009; Smith \& Keil, 2003) to unmanaged commitment escalation. Sunk costs and identification of personal responsibility are two explanations of individual cognitions that have been associated with commitment failures (Desai \& Chulkov, 2009; Smith \& Keil, 2003). Taken together, the positive behaviors and dysfunctions show that organizational commitment can be a key force in directing employee work outcomes.

Consideration of organizational politics rests somewhere between required role behavior and unsanctioned efforts (Zanzi \& O'Neill, 2001). Political behavior is often an attempt to influence the distribution of resources and outcomes in the organization (Sussman, Adams, Kuzmits, \& Raho, 2002) which can, in turn, have substantial impact on the development and maintenance of organizational commitment. Studies indicate political behavior in organizations is typically perceived as non-sanctioned, manipulative, self-interested and is often construed negatively (Poon, 2003; Vigoda, 2000a, 2000b). Alternatively, others have argued that well managed political skills can positively influence work outcomes (Treadway, Hochwarter, Kacmar, \& Ferris, 2005), especially information sharing (Gupta, 2011). The key to understanding how politics influences organizational commitment is focusing on the employee subjective experience of politics (Gandz \& Murrey, 1980; Ferris, Russ, \& Fandt, 1989). Focusing on the perceptions of organizational politics refines the notion of organizational politics making it an individual, perceptual and subjective construct with proximal cognitive access to the development of individual attitudes, such as organizational commitment. 
A known moderator of organizational contextual factors is individual psychological empowerment (Avolio, Zhu, Kho, \& Bhata, 2004). The empowerment concept (Spreitzer, 1995) has proven to be a useful and sophisticated construct producing both a micro-perspective focusing on concepts; for example, self-efficacy and meaningfulness, and a macro-perspective focusing on delegation of decision-making and information sharing. As the research has evolved (Thomas \& Velthouse, 1990; Moye, Henkin, \& Egley, 2004; Ergeneli, Sag, Ari, \& Metin, 2007), a fourdimensional model of empowerment focusing on competence, meaning, impact and self-determination has become standard.

The necessity of testing the moderators for the political behavior/organizational commitment relationship has emerged in prior research. Specifically referencing Pakistan and referring generally to developing organizations, one study (Bodla \& Hussain, 2010) cites the need for effective leadership styles to manage employees. This study also notes the need to generalize managerial theory to non-Western work organizations. Further, a study of transformational leadership in Singapore (Avolio, Zhu, Kho, \& Bhata, 2004) demonstrated that psychological empowerment was an important moderator for organizational commitment.

\section{HYPOTHESES}

H1 Perceptions of organizational politics are negatively associated with organizational commitment.

H2 Higher levels of psychological empowerment are associated with lower levels of perceived organizational politics.

H3 Increased levels of psychological empowerment moderate the relationship between organizational politics and organizational commitment.

\section{METHODS}

\section{Sample}

The obtained sample ( $\mathrm{N}=357)$ is of employed persons who are part-time graduate students of economics or business. Data were collected at five universities in Pakistan - three in Lahore and two in Islamabad. The sample is 70.9 percent male with 46.1 percent under age 40. The respondents report themselves as 11.8 percent upper management, 43.7 percent middle management, 25.8 percent first level management and 18.8 percent workforce. Fifty-five percent of the respondents have five years or less experience and 26.1 percent have more than ten years experience. The largest category was 20,000 to 60,000 rupees per month income. The exchange rate of rupees to dollars is approximately 85 to 1 .

\section{Measures}

Organizational commitment is measured using the 14-item scale with three documented subscales (Allen \& Meyer, 1990) - affective commitment (six items; "I would be happy to spend the rest of my career"), normative commitment (four items; "This organization deserves my loyalty"), and continuance commitment (four items; "Right now, staying with my organization is a matter of necessity). The measure of organizational politics uses 18 items and focuses on three dimensions - political behavior ("People in this organization attempt to build themselves up by tearing others down"), going along to get along ("Agreeing with powerful others is the best alterative"), and pay and promotion policies ("Promotions around here are not valued much because how they are determined is so political"). The items were selected from surveys of the Perceptions of Organizational Politics Scale (Ferris \& Kacmar, 1992). The 16-item psychological empowerment scale has four dimensions - competence ("I am really confident about my ability to do the job"), meaning ("My job activities are personally meaningful to me."), impact (e.g. "I have a great deal of control over what happens in my department"), and self-determination ("I can decide on my own how to go about doing my own work"). All questionnaires were presented in English (Thomas \& Velthouse, 1990). 


\section{RESULTS OF FACTOR ANALYSIS}

The measures of the three variables of interest - organizational commitment, organizational politics, and psychological empowerment - were subjected to first order confirmatory factor analysis and structural equation modeling to test validity of the measurement as applied in a non-Western culture. The applications of structural equation modeling were executed using the EQS/Window program (Bentler, 1989, 1992). Four criteria for assessing fit were used: $\mathrm{X}^{2}, \mathrm{X}^{2} / \mathrm{df}$, the probability of the $\mathrm{X}^{2} / \mathrm{df}$ measure, and the Comparative Fit Index (CFI). The $\mathrm{X}^{2} / \mathrm{df}$ measure was utilized to balance the impact of sample size on significance. Ideally, values should be below 3.0. The comparative fit index was included to test acceptability of covariation within the data set with values greater than .90 indicating acceptable fit to the data.

All three concepts, based on extensive prior research, met expectations of the confirmatory factor analysis. For organizational commitment, its three dimensions produced well-balanced factor leadings. The $\mathrm{X}^{2}$ (Chi square $)=295.14, X^{2} / d f=2.19, p>.001$ and the comparative fit indices were all greater than .9 . For the organizational politics measure, the $\mathrm{X}^{2}=777.0$, the $\mathrm{X}^{2} / \mathrm{df}=1.44, \mathrm{p}>.001$ and all CFI were greater than .9 . For the psychological empowerment index, the $\mathrm{X}^{2}=13.79, \mathrm{X}^{2} / \mathrm{df}=1.38, \mathrm{p}>.03$ and all loadings $\mathrm{p}>.9$. Figure 1 presents the full, second order structural equation model with EQS notations.

Figure 1: Full Structural Equation Model with EQS Notation

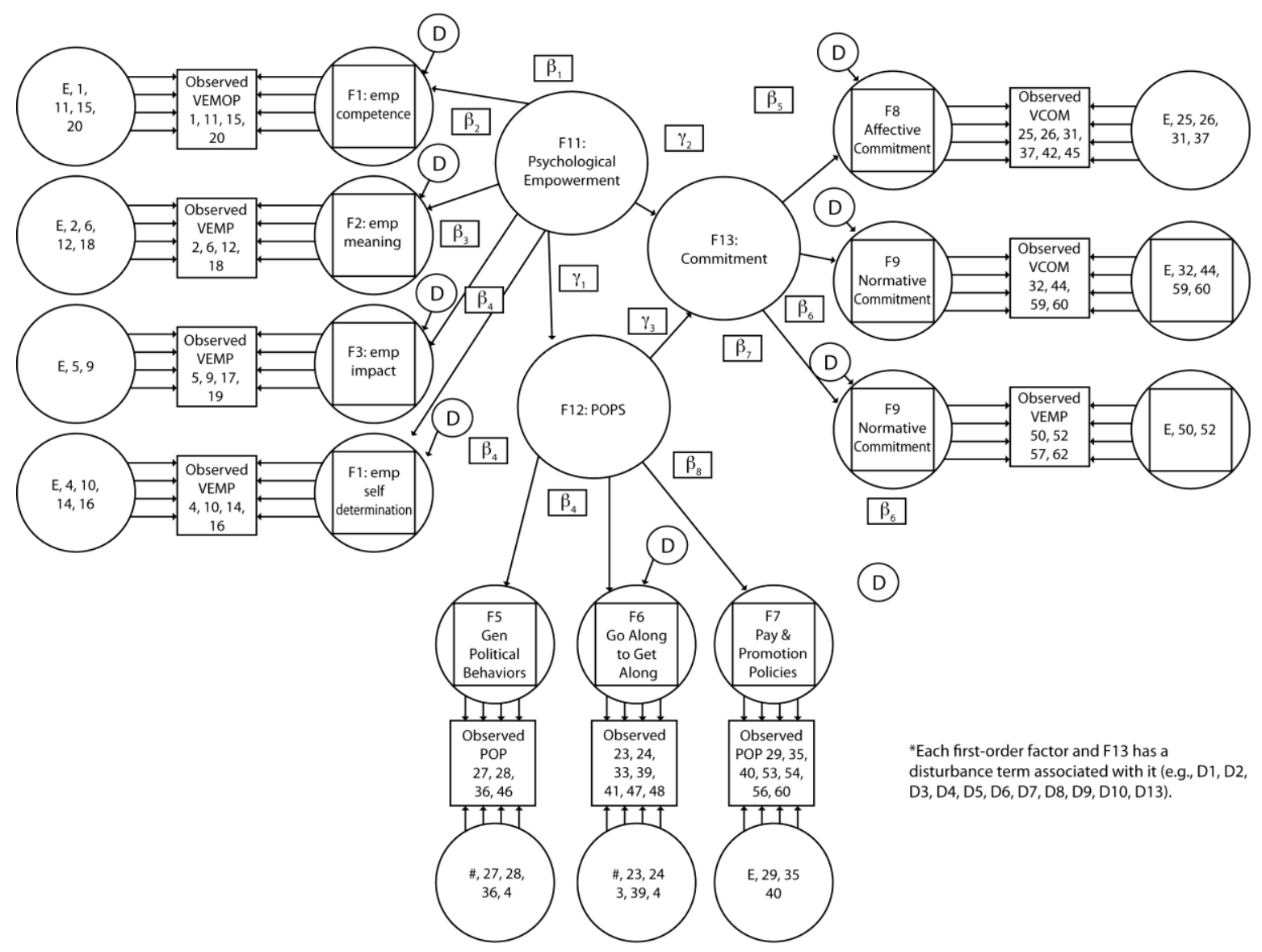




\section{TESTING MODERATOR EFFECTS}

Figure 2 displays a structural equation model where organizational politics is regressed onto organizational commitment. The test statistics are: $X^{2}=202.7$, the $X^{2} / d f=2.20, p<.05$. The beta coefficient for this relationship is .966. Simply stated, in this sample there is a significant negative direct effect for organizational politics on organizational commitment.

Figure 2: Relationship Between Politics and Commitment

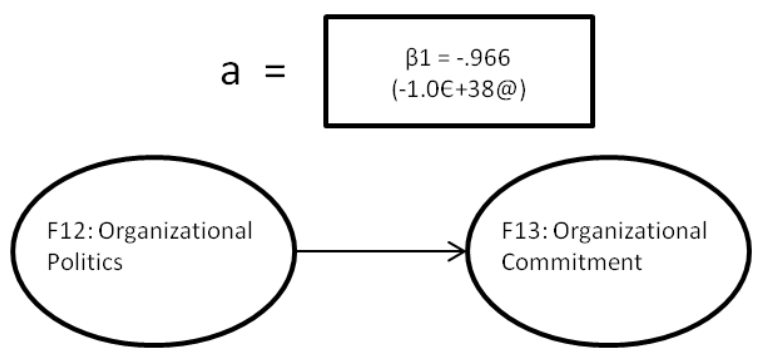

Figure 3 presents a larger structural equation model that includes psychological empowerment as a possible moderator between organizational politics and organizational commitment. Again, the test statistics are: $\mathrm{X}^{2}=493.10$, $\mathrm{X}^{2} / \mathrm{df}=1.98$, all betas are significant at $\mathrm{p}>.05$. Most interestingly, the beta for the politics on commitment relation is now positive 2.548. These findings support the notion that psychological empowerment moderates the relationship between organizational politics and organizational commitment.

Figure 3: How Empowerment Moderates the Politics/Commitment Relationship

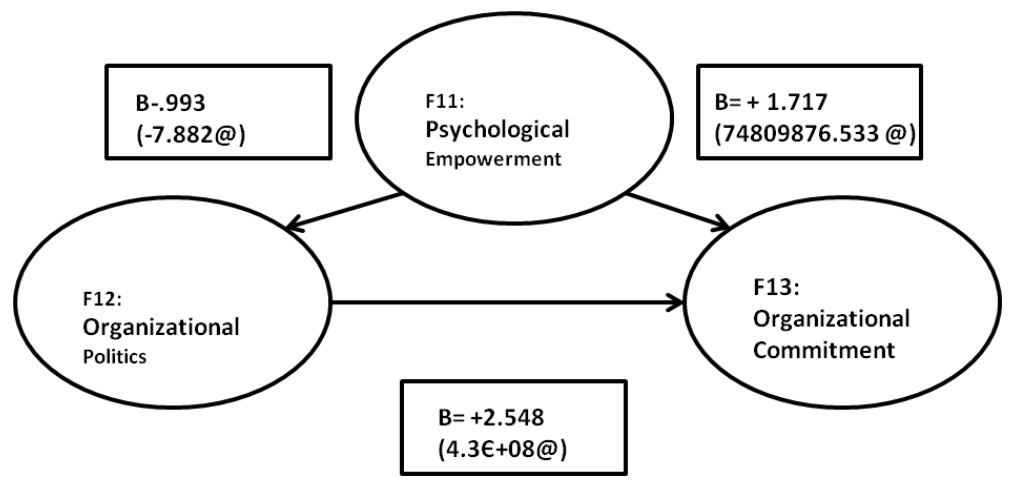

\section{DISCUSSION AND CONCLUSION}

The forgoing data support all three hypotheses - organizational commitment is impacted by organizational politics and psychological empowerment. More specifically, psychological empowerment positively moderates the relationship between politics and commitment. These effects strongly support management and leadership styles, providing increases in employee autonomy, perceived meaningfulness of work, perceived self-efficacy and impact of employees' work within the organization. Further, these findings suggest, in a very initial way, that existing social psychological theories of employee organizational relationships may be applicable in non-Western work cultures. 
Organizational commitment is recognized as a key employee attitude. It has positive benefits across an array of outcomes and, only occasionally, adverse potential, as in the cases of unwarranted escalation of information system projects. Focusing on organizational politics appears to be a fruitful and growing perspective. This research supports and clarifies managers' understanding of organizational politics. Politics may be viewed and, indeed, may have non-sanctioned and negatively perceived dimensions. When psychological empowerment develops among employees, organizational politics can be a positive force in organizations.

\section{AUTHOR INFORMATION}

Naheed Atta is an Associate Professor of Psychology at Govt. Post Graduate Islamia College(w), Lahore. Her research interests include employee commitment and transformational leadership.

Dr. Muneer Ahmad was a Professor of Sociology at the University of Punjab-Lahore. He is now a senior research scholar at the Lahore School of Economics.

Dr. I. U. Mangla is a Professor of Finance. His interests are in developing markets and financial reforms in South Asian economies. He has consulted for the World Bank. He has recently completed a Fullbright Fellowship in Pakistan.

Dr. Dan Farrell is a Professor of Management. His interests include employee responses to dissatisfaction and organizational politics. E-mail: dan.farrell@wmich.edu. Corresponding author.

\section{REFERENCES}

1. Allen, N. J., \& Meyer, J. P. (1990). The measurement and antecedent of affective, continuance, normative commitment to the organization. Journal of Occupational and Organizational Psychology, 63(1), 1-18.

2. Antoncic, J. A., \& Antoncic, B. (2011). Employee loyalty and its impact on firm growth. International Journal of Management \& Information Systems, 15(1), 81-87.

3. Avolio, B. J., Zhu, W., Kho, W., \& Bhata, P. (2004). Transformational leadership and organizational commitment: Mediating role of psychological empowerment and moderating role of structural distance. Journal of Organizational Behavior, 24, 1-18.

4. Bentler, P. M. (1989). EQS: Structural Equations Program Manual. Los Angeles: BMDP Statistical Software.

5. Bentler, P. M. (1992). EQS: Structural Equations Program Manual. Los Angeles: BMDP Statistical Software.

6. Bodla, M. A., \& Hussain, G. (2010). Need for leadership: Empirical evidence from Pakistan. International Journal of Management \& Information Systems, 14(5), 79-86.

7. Cropanzano, R., Rupp, D. E., \& Byrne, Z. S. (2003). The relationship of emotional exhaustion to work attitudes, job performance, and organizational citizenship behaviors. Journal of Applied Psychology, 88, 160-169.

8. Desai, M. S., \& Chulkov, D. V. (2009). Escalation of commitment in MIS projects: A meta-analysis. International Journal of Management \& Information Systems, 13(2), 29-86.

9. Ergeneli, A., Sag, G., Ari, I., \& Metin, S. (2007). Psychological empowerment and its relationship to trust in immediate managers. Journal of Business Research, 60(1), 41-56.

10. Ferris, G. R., Russ, G. S., \& Fandt, P. M. (1989). Politics in organizations. In R. A. Giacalone \& P. Rosenfeld (Eds.), Impression management in the organization (pp. 143-170). Hillsdale NJ: Erlbaum.

11. Ferris, G. R., \& Kacmar, K. M. (1992). Perceptions of organizational politics. Journal of Management, 18(1), 93-116.

12. Gandz, J., \& Murrey, V. V. (1980). The experience of work place politics. Academy of Management Journal, 23, 237-251.

13. Gupta B. (2011). Employees' knowledge sharing behavior and work engagement: The role of organisational politics. International Journal of Business Excellence, 4(2), 160-177.

14. Mowday, R., Porter, L., \& Steers, R. (1982). Organizational Linkages: The Psychology of Commitment, Absenteeism, and Turnover. New York, NY: Academic Press. 
15. Moye, M. J., Henkin, A.B., \& Egley, R.J. (2004). Teacher-principal relationships: Exploring linkages between empowerment and interpersonal trust. Journal of Educational Administration, 43(3), 260-277.

16. Poon, J. M. L. (2003). Situational antecedents and outcomes of organizational politics perceptions. Journal of Managerial Psychology, 18(2), 138-155.

17. Rusbult, C. E., Farrell, D., Rogers, G., \& Mainous III, A. G. (1988). Impact of exchange variables on exit, voice, loyalty, and neglect: An integrative model of responses to declining job satisfaction. The Academy of Management Journal, 31(3), 599-627.

18. Smith, H. J., \& Keil, M. (2003). The reluctance to report bad news on troubled software projects: A theoretical model. Information Systems Journal, 13, 69-95.

19. Spreitzer, G. M. (1995). Psychological empowerment in the workplace: Dimensions, measurement, and validation. The Academy of Management Journal, 38(5), 1442-1465.

20. Sussman, L., Adams, A. J., Kuzmits, F. E., \& Raho, L. E. (2002). Organizational politics: Tactics, channels, and hierarchical roles. Journal of Business Ethics, 40, 313-329.

21. Thomas, K. W., \& Velthouse, B. A. (1990). Cognitive elements of empowerment: An "interpretive" model of intrinsic task motivation. Academy of Management Review, 15(4), 666-681.

22. Treadway, D., Hochwarter, W., Kacmar, C., \& Ferris, G. (2005). Political will, political skill, and political behavior. Journal of Organizational Behavior, 26, 226-245.

23. Vigoda, E. (2000a). Internal politics in public administration systems: An empirical examination of its relationship with job congruence, organizational citizenship behavior, and in-role performance. Public Personnel Management, 29, 185-210.

24. Vigoda, E. (2000b). The relationship between organizational politics, job attitudes, and work outcomes: exploration and implications for the public sector. Journal of Vocational Behavior, 57, 326-347.

25. Zanzi, A., \& O’Neill, R. M. (2001). Sanctioned versus non-sanctioned political tactics. Journal of Managerial Issues, 13(2), 245-262. 